\title{
Dynamics of bacterioplankton abundance and production in seagrass communities of a hypersaline lagoon
}

\author{
Gerardo Chin-Leo, Ronald Benner
}

University of Texas at Austin, Marine Science Institute, Port Aransas, Texas 78373-1267, USA

\begin{abstract}
The significance of bacterioplankton in the flow of carbon and energy and in trophic dynamics of the upper Laguna Madre, Texas (USA), was estimated by measuring bacterioplankton abundance and production over an $18 \mathrm{mo}$ period and over several diel cycles. Bacterioplankton production was estimated from incorporation rates of thymidine (DNA synthesis) and leucine (protein synthesis). These independent indices of bacterial growth were generally in agreement and yielded nearly identical annual estimates of bacterial production $\left(25.24 \mathrm{~g} \mathrm{C} \mathrm{m}^{-2} \mathrm{yr}^{-1}\right.$ based on thymidine and $25.12 \mathrm{~g} \mathrm{C} \mathrm{m}^{-2} \mathrm{yr}^{-1}$ based on leucine). Assuming a $30 \%$ growth efficiency, the annual bacterioplankton growth could be supported by $15 \%$ of the total primary production (seagrasses and phytoplankton), $17 \%$ of the above-ground production of the dominant seagrass, Halodule wrightii, or $103 \%$ of the phytoplankton production. Bacterial abundance was high throughout the year, often exceeding $1 \times 10^{10}$ cells $1^{-1}$. Bacterioplankton production varied seasonally and over the diel cycle, with maximal values during warmer months and during daytime. Although changes in water temperature could account for some of this variation, shifts in the quantity and quality of the organic substrates supporting bacterial growth appeared to be the major factors regulating the variations in bacterioplankton production. Bacterioplankton in the Laguna Madre are a large and rapidly growing source of biomass potentially available for higher trophic levels. If this biomass is efficiently used by grazers, bacteria may be a major 'link' between seagrass production and secondary producers in the Laguna Madre ecosystem.
\end{abstract}

\section{INTRODUCTION}

Shallow coastal lagoons biologically are highly productive systems (Nixon 1982) that form nearly $13 \%$ of the world's coastline (Cromwell 1971). The Laguna Madre in Texas is unique among these marine environments in that it receives essentially no freshwater inflow and has very limited exchange with the sea (Hedgpeth 1967). These features, in addition to the high temperatures and levels of solar radiation characteristic of south Texas, result in warm, hypersaline waters with temperatures and salinities typically reaching $30^{\circ} \mathrm{C}$ and $55 \%$ during summer (Hedgpeth 1947 , present study). In spite of these apparently harsh conditions and the lack of riverine sources of inorganic nutrients, the Laguna Madre supports a substantial biological production (Odum \& Wilson 1962, Hedgpeth 1967). For example, the average annual finfish harvest from the Laguna Madre, which accounts for approximately $30 \%$ of the bay area on the Texas coast (NOAA 1985), generally exceeded the combined catch from all the other bays in Texas (Texas Parks and Wildlife Dept 1988).

Extensive seagrass beds dominate primary production in Laguna Madre and have been implicated in supporting the high secondary productivity of this system (Odum \& Wilson 1962). Direct evidence for the importance of seagrass-derived carbon in animal production comes from comparisons of the stable carbon isotope compositions of seagrasses in animals in Laguna Madre. The carbon isotopic signatures of many animals, including top carnivores such as redfish and seatrout, indicate a strong influence of seagrassderived carbon (Fry \& Parker 1979, P. Parker unpubl.). Although there is ample evidence for the role of seagrasses in supporting the secondary productivity of Laguna Madre, the pathways and mechanisms for the transfer of seagrass production to animals have not been elucidated. Seagrasses are not directly utilized by most animals because they are composed primarily of structural polysaccharides and contain phenolic compounds that decrease their palatability (Valiela et al. 
1979. Mann 1988). Most of the seagrass production becomes available for consumption by animals indirectly through the senescence and decomposition of seagrass detritus (Mann 1988).

Bacteria may be particularly important in the flow of carbon and nitrogen in seagrass communities because bacteria account for most of the degradation of vascular plant tissues in marine systems (Benner et al. 1986b). In addition, bacteria consume the dissolved organic matter (DOM) leached from plant detritus (Benner et al. 1986c, Findlay et al. 1986, Moran \& Hodson 1989) and the DOM released by seagrasses during photosynthesis (Moriarty et al. 1986). Bacterial production in seagrassdominated ecosystems can be substantial. In seagrass meadows of Australia, the total heterotrophic bacterial production (sediments and the water column) could account for nearly half of the total primary production (Moriarty et al. 1990). The utilization of seagrassderived detritus by bacteria, and the consumption of bacterial biomass by grazers (the microbial loop) may be important mechanisms for the transfer of seagrassderived organic matter to aquatic food webs. Whether bacteria are 'sinks' or 'links' for carbon transfer in phytoplankton-based (Ducklow et al. 1986, Sherr et al. 1987) and detritus-based (Moran et al. 1988) ecosystems remains a source of debate.

In the present study, we measured the abundance and production of bacteria in the water column (bacterioplankton) of the upper Laguna Madre to estimate their role in carbon and energy flow, and to determine the potential of bacteria as a 'link' in the food web of this ecosystem.

\section{MATERIALS AND METHODS}

Study site, station locations and sampling procedure. The Laguna Madre is located at the southern end of the Texas Gulf Coast (Fig. 1). This shallow lagoon (mean depth $=1.0 \mathrm{~m}$ ) stretches $200 \mathrm{~km}$ from Corpus Christi Bay southward to the Rio Grande. This study focused on the upper Laguna Madre between Corpus Christi Bay and Baffin Bay, where primary production is dominated by the seagrass Halodule wrightii. Three stations in the upper Laguna Madre were sampled. The King Ranch (KR) station (depth $=1.2 \mathrm{~m}$ ) is near the western shore, Stn $A$ (depth $=1.3 \mathrm{~m}$ ) is located $11 \mathrm{~km}$ to the south near the intracoastal waterway, and Stn B (depth $=1.2 \mathrm{~m}$ ) is located near Baffin Bay (Fig. 1). In addition, we sampled in Baffin Bay (Stn C, depth $2.5 \mathrm{~m}$ ), a system adjacent to Laguna Madre where primary production is dominated by phytoplankton (Fig. 1). Water samples were collected in $250 \mathrm{ml}$ glass BOD bottles attached to an aluminum pole. Bottles were submerged closed and were opened at a depth of

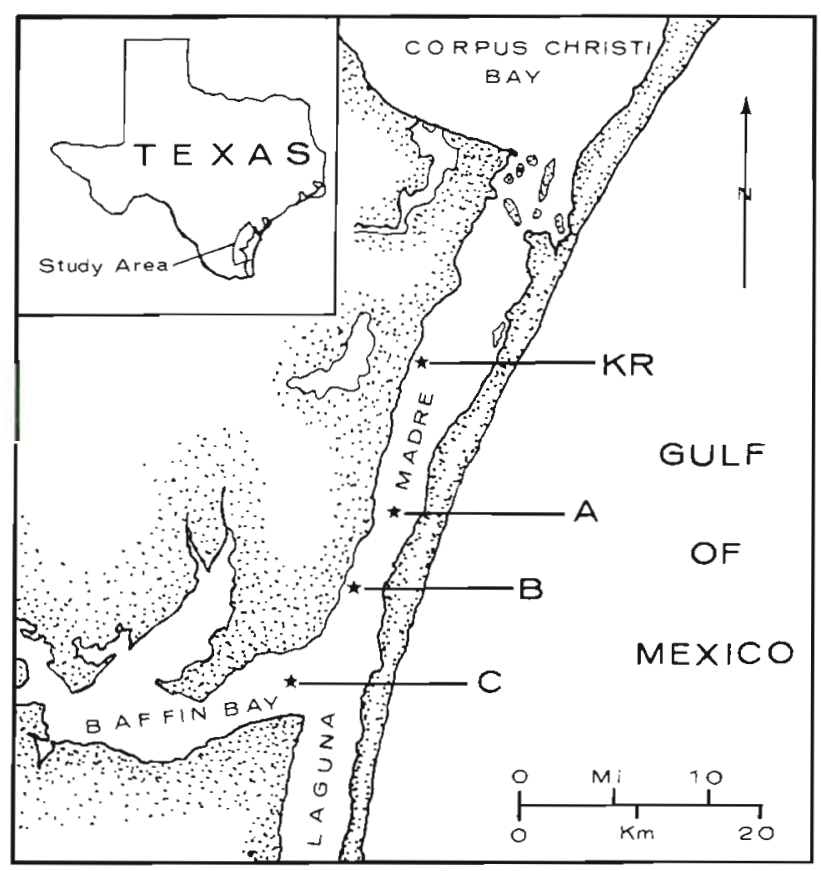

Fig. 1 Location of Stns A, B, C and KR in the upper Laguna Madre

$1 \mathrm{~m}$ by pulling a string attached to the bottle's stopper. Samples were stored in the dark, submerged in water collected from the same site and transported to the laboratory within $1 \mathrm{~h}$. In July 1989 comparisons were made between measurements of bacterial abundance and production in samples processed immediately after collection and those from replicate samples analyzed after $1 \mathrm{~h}$. No significant differences were found between these samples. Salinity was measured with a Reichert refractometer.

Bacterial abundance and production. Bacterial abundance was measured using epifluorescence microscopy of DA.PI-stained samples (Porter \& Feig 1980). Samples were analyzed in duplicate. Bacteria in at least 10 fields were counted for each microscope slide (Kirchman et al. 1982b). Bacterial production was estimated from rates of DNA and protein syntheses as measured by rates of incorporation of labeled thymidine (TdR) (Fuhrman \& Azam 1982) and leucine (Leu) (Kirchman et al. 1985) respectively. A modified version of a dual-label method (Chin-Leo \& Kirchman 1988) was used to simultaneously measure these independent indices of bacterial growth. The substrate concentrations and the incubation time used were determined from substrate saturation curves and time-course experiments. These experiments were conducted in November 1988 and in March and September 1989. TdR and Leu incorporation was linear for $90 \mathrm{~min}$, and incorporation was saturated at $10 \mathrm{nM}$ TdR and $20 \mathrm{nM}$ Leu. 
Triplicate water samples $(10 \mathrm{ml})$ were incubated with $10 \mathrm{nM}$ (final concentration) $\left[{ }^{3} \mathrm{H}\right] \mathrm{TdR}$ (specific activity $84.1 \mathrm{Ci} \mathrm{mmol}{ }^{-1}$ ), and $20 \mathrm{nM}$ (final concentration) ${ }^{14} \mathrm{C}$ Leu (specific activity $328.5 \mathrm{mCi} \mathrm{mmol}^{-1}$ ) for $30 \mathrm{~min}$. All radioactive substrates were from New England Nuclear (Boston, Massachusetts, USA). Incubations were ended by cooling samples in ice for $2 \mathrm{~min}$ and filtering them through Nuclepore MF filters (0.2 $\mathrm{mm}$ pore size). Macromolecules were extracted by treating the filter with $2 \mathrm{ml}$ of ice-cold $5 \%$ trichloroacetic acid (TCA) for $2 \mathrm{~min}$. The extent of TdR metabolism by bacteria was estimated for all samples by measuring $\left[{ }^{3} \mathrm{H}\right]$ incorporated into the protein fraction. To separate the protein and nucleic acid fractions, the filter was placed in a scintillation vial with $2 \mathrm{ml}$ of $5 \%$ TCA and heated to $95^{\circ} \mathrm{C}$ for $30 \mathrm{~min}$. After the vial was cooled to room temperature, the filter was separated from the TCA by passing the TCA through a second Nuclepore MF filter, Following a $1 \mathrm{ml}$ rinse with $5 \% \mathrm{TCA}$, the 2 filters (proteins) and filtrate (nucleic acids) were collected in separate scintillation vials and radioassayed.

Rates of incorporation of radiolabeled substrates were converted to rates of bacterial production using conversion factors determined empirically by comparing, under controlled conditions, isotope incorporation with increases of bacterial numbers (Kirchman et al. 1982a, Riemann et al. 1987). Conversion factors were derived at various times of the year (exact dates are given in 'Results'). Generation times of bacteria, $(\ln 2) / \mu$, were also derived from changes in cell density in these dilution cultures $[\mu=$ slope of $\ln$ (cell abundance) versus time]. The plot of ln (cell abundance) vs time was always linear $\left(\mathrm{r}^{2}>0.86, \mathrm{p}<0.05\right)$. All points were used to calculate the slope. An exception was the September 1989 experiment, when cell abundances decreased after $26 \mathrm{~h}$. The values following this decrease were not considered when calculating the regression equation. Generation times were compared to the turnover time of bacteria (ratio of abundance/production). For this comparison, we used the rate of production based on rates of $\mathrm{TdR}$ incorporation.

Seasonal and diel variations in bacterial production and abundance. Approximately every month, from October 1988 to March 1990, Stn KR was sampled in duplicate at approximately 10:00 h (local time). In addition, from March 1989 to January 1990, Stns KR, A, B and $C$ were surveyed every other month. Stns were sampled from a motorboat at various times of the day and taken immediately to a site near Stn $C$ where the RV 'Longhorn' was anchored. Samples were collected in duplicate at each station and were processed within 30 min of collection. Differences in the bacterial parameters between stations in Laguna Madre were small, and a seasonal curve for bacterial production was constructed from the average of values from Stns KR, A and $\mathrm{B}$. To remove the diel variation in bacterial production only daytime values were used. The relative importance of free-living and attached bacteria was examined during September and November 1988 and January and February 1989 at Stn KR. Incorporation of $T d R$ by free-living bacteria was estimated from the difference in rates of TdR incorporation between whole water samples and replicate samples filtered through Nuclepore filters ( $3 \mu \mathrm{m}$ pore size).

In May and July 1989, bacterial abundance and production were measured in Laguna Madre over diel cycles to test for the possible rapid utilization by bacteria of DOM released during photosynthesis. During each sampling point, the water column over vegetated and over adjacent unvegetated sediments was sampled. In May, a transect was marked at Stn A with 7 PVC poles placed $3 \mathrm{~m}$ apart. Three poles were placed in unvegetated sediments and 2 poles were set on either side over seagrasses. Samples were obtained near each pole at $4 \mathrm{~h}$ intervals for $24 \mathrm{~h}$. A similar survey was performed in July at the same location. On this occasion 3 poles were placed $1 \mathrm{~m}$ apart over seagrasses. A similar pattern was used in adjacent unvegetated sediments and samples were collected every $4 \mathrm{~h}$ for $48 \mathrm{~h}$. Samples were taken from a small rowboat to minimize disruption of the water column. All samples were analyzed in duplicate. Direction and speed of the surface currents were estimated by observing the trajectory of a neutrally buoyant float (a grapefruit) and by measuring the time that the float took to travel $7 \mathrm{~m}$. In July, samples were also obtained over 2 diel cycles from Baffin Bay (Stn C). Baffin Bay samples were collected within 30 min of those collected in Laguna Madre.

Response of natural assemblages of bacteria to changes in water temperature. The response of Laguna Madre bacteria to diel changes in water temperature was determined from changes in rates of $T d R$ and Leu incorporation of bacteria incubated at a range of temperatures representative of spring and summer values. A 20 I water sample was collected from Stn KR in July and in August 1989. Triplicate subsamples $(10 \mathrm{ml})$ were incubated with $\left[{ }^{3} \mathrm{H}\right] \mathrm{TdR}$ and $\left[{ }^{14} \mathrm{C}\right]$ Leu for $1 \mathrm{~h}$ in each of 5 water baths held at $22,25,28,32$ and $36^{\circ} \mathrm{C}$. Following the incubation period, samples were processed as described previously for bacterial production.

\section{RESULTS}

\section{Seasonal variations in bacterial production and abundance}

During this study, rates of $T d R$ and Leu incorporation generally paralleled each other $(r=0.62, p=0.02)$ 
(Fig. 2A). However, changes in rates of $\mathrm{TdR}$ and Leu incorporation did not always coincide, and the Leu : TdR ratio (mean $=32 \pm 16$ ) varied over the study period (Fig. 2B). Free-living bacteria were the major component of the bacterioplankton and accounted for a mean of $74 \pm 17 \%$ of total $\mathrm{TdR}$ incorporation. In September 1988, bacteria associated with particles accounted for a significant fraction of TdR incorporation $(44 \%)$. Sediment resuspension due to the passage of a frontal weather system prior to our sampling may explain this high value. The percent of TdR recovered in the protein fraction did not exhibit any seasonal trend and averaged $40 \pm 3(\mathrm{SE}) \%(\mathrm{range}=19$ to $57 \%$ ) (Table 1). A similar value $[45 \pm 2$ (SE) \%] was calculated for Baffin Bay samples.
Water temperature ranged from 12 to $30^{\circ} \mathrm{C}$ with a mean of $21 \pm 6^{\circ} \mathrm{C}$, and salinity ranged from 33 to $55 \%$ with a mean of $44 \pm 6 \%$ (Fig. 2C). Salinities were generally highest during the warmer summer months and lowest during winter and spring. However, during storms salinity may change abruptly. For example, on 26 October 1989 salinity decreased by $12 \%$ due to heavy rainfall (Fig. 2C). Changes in bacterial production appeared to reflect variations in water temperature. In 1990, rates of $\mathrm{TdR}$ and Leu incorporation in Laguna Madre were higher in warmer months between July and November than during cooler months between December and March (Fig. 2A). The correlation coefficient between temperature and the rate of uptake of Leu was $r=0.68(p=0.01)$, whereas for $\mathrm{TdR}$
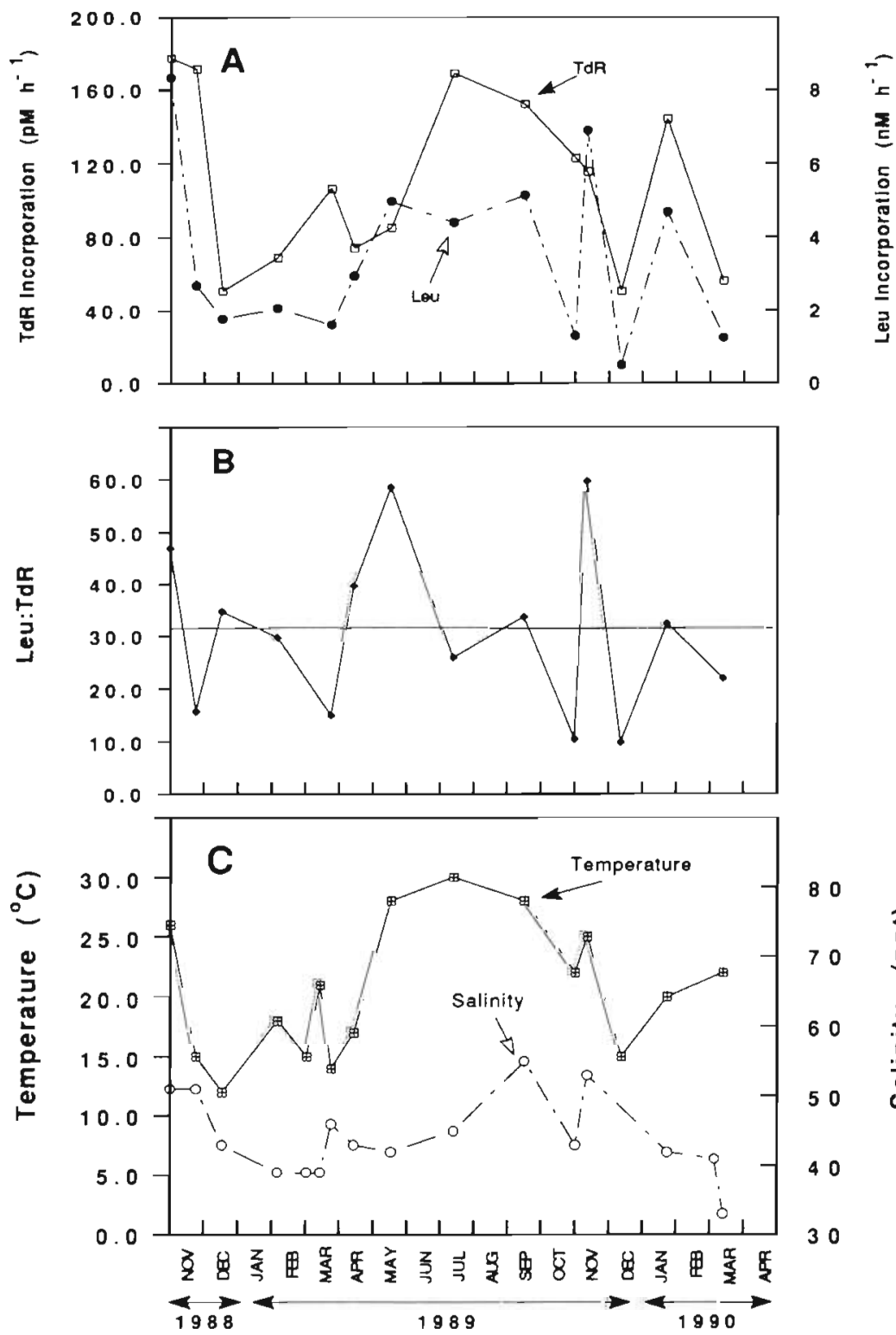

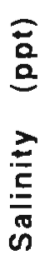

Fig. 2. Seasonal variations in (A) incorporation rates of thymidine (TdR) and leucine (Leu), (B) the Leu: $\mathrm{IdR}$ ratio and (C) water temperature and salinity. Horizontal line in (B) represents the average Leu: TdR value of 32 
Table 1. Seasonal variations in water temperature, bacterial abundance, specific incorporation of labeled thymidine (TdR) and leucine (Leu), and percentage $\left[{ }^{3} \mathrm{H}\right]$ from $\mathrm{TdR}$ recovered in the protein fraction

\begin{tabular}{|cccccc|}
\hline Date & $\begin{array}{c}\text { Water temp. } \\
\left({ }^{\circ} \mathrm{C}\right)\end{array}$ & $\begin{array}{c}\text { Abundance } \\
\left(10^{9} \text { cells } l^{-1}\right)\end{array}$ & $\begin{array}{c}\text { TdR incorp. } \\
\left(10^{-8} \mathrm{pM} \mathrm{cell}^{-1} \mathrm{~h}^{-1}\right)\end{array}$ & $\begin{array}{c}\text { Leu incorp. } \\
\left(10^{-10} \mathrm{nM} \mathrm{cell} \mathrm{n}^{-1}\right)\end{array}$ \\
\hline 1988 in $\mathrm{protein}^{-1}$ \\
\end{tabular}

it was $r=0.49(\mathrm{p}=0.08)$. Rates of bacterial production during the beginning of 1990 differed from corresponding values in 1989. In January 1990, rates of TdR and Leu incorporation were among the highest measured (Fig. 2A). Water temperature in January 1990 was $8^{\circ} \mathrm{C}$ higher than that measured in January 1989 (Fig. 2C), and samples were collected 2 wk after a severe freeze that led to massive fish kills in Laguna Madre.

Mean bacterial abundance was $7.7 \pm 1.9 \times 10^{9}$ cells $1^{-1}$. Cell densities exceeded $1.0 \times 10^{10}$ cells $1^{-1}$ in October 1988 and March and November 1989 (Table 1). These high densities were not sustained throughout the year and decreased between July and September 1989, even though rates of bacterial production remained high (Table 1 ). The seasonal variations in rates of radioisotope incorporation per bacterium were similar to those of total incorporation, with higher values in warmer months (May to October 1989) than in cooler months (December 1988 to March 1989) (Table 1).
Conversion factors for $\mathrm{TdR}$ and Leu incorporation varied over the year (Table 2). Dilution experiments used to determine conversion factors were not replicated, and therefore we do not know the precision of these estimates. The mean of these values was used to calculate annual bacterial production. The mean conversion factor for $\mathrm{TdR}$ was $1.26 \pm 0.80 \times 10^{18}$ cells $\mathrm{mol}^{-1}$ and for Leu was $4.27 \pm 3.31 \times 10^{16} \mathrm{cells} \mathrm{mol}^{-1}$ (Table 2). Bacterial size in Laguna Madre ranged from 0.05 to $1.00 \mu \mathrm{m}^{3}$, which is similar to the range for other marine bacteria (Lee \& Fuhrman 1987). Using the conversion factors calculated from the present study and values of $20 \mathrm{fg} C$ and $6 \mathrm{fg} \mathrm{N}$ per bacterial cell (Lee \& Fuhrman 1987), the annual rate of bacterial production on an areal basis (depth $=1 \mathrm{~m}$ ) for the upper Laguna Madre was $25.24 \mathrm{~g} \mathrm{C}$ and $7.57 \mathrm{~g} \mathrm{~N} \mathrm{~m}^{-2} \mathrm{yr}^{-1}$ based on

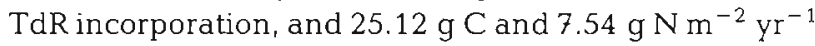
based on Leu incorporation. Daily rates of bacterial carbon and nitrogen production ranged from 19 to $108 \mathrm{mg} \mathrm{C} \mathrm{m}^{-2} \mathrm{~d}^{-1}$ and from 6 to $32 \mathrm{mg} \mathrm{N} \mathrm{m}^{-2} \mathrm{~d}^{-1}$ based

Table 2. Generation times, biomass turnover times, and conversion factors for labeled thymidine (TdR) and leucine (Leu) from Laguna Madre. Conversion factors were derived empirically using dilution cultures. Generation times, (ln 2)/ $\mu$, were derived from the increase of cell numbers in the dilution cultures. Tumover times were computed from bacterial abundance (cells $1^{-1}$ ) and production (cells $\mathrm{I}^{-1} \mathrm{~h}^{-1}$ )

\begin{tabular}{|lcccc|}
\hline Date & $\begin{array}{c}\text { Generation } \\
\text { time (h) }\end{array}$ & $\begin{array}{c}\text { Turnover } \\
\text { time }(\mathrm{h})\end{array}$ & \multicolumn{2}{c|}{$\begin{array}{c}\text { Conversion factors } \\
\left(10^{18} \mathrm{cells} \mathrm{mol}^{-1}\right)\end{array}$} \\
$\left(10^{16} \mathrm{cells} \mathrm{mol}^{-1}\right)$ \\
\hline 10 Feb 1989 & 31 & 91 & 1.47 & 1.73 \\
30 Mar 1989 & 32 & 70 & 1.03 & 0.59 \\
12 Apr 1989 & 40 & 84 & 0.73 & 8.14 \\
15 Sep 1989 & 33 & 36 & 2.55 & 0.54 \\
15 Jan 1990 & 22 & 37 & 0.31 & 1.31 \\
\hline
\end{tabular}


Table 3. Bacterial abundance and rates of labeled thymidine (TdR) and leucine (Leu) incorporation in the Laguna Madre and Baffin Bay

\begin{tabular}{|c|c|c|c|c|c|c|}
\hline \multirow[t]{2}{*}{ Date } & \multicolumn{3}{|c|}{ Laguna Madre } & \multicolumn{3}{|c|}{ Baffin Bay } \\
\hline & $\begin{array}{l}\text { Abundance } \\
\left(10^{9} \text { cells } 1^{-1}\right)\end{array}$ & $\begin{array}{l}\text { TdR incorp. } \\
\left(\mathrm{pM} \mathrm{h}^{-1}\right)\end{array}$ & $\begin{array}{l}\text { Leu incorp. } \\
\left(\mathrm{nM} \mathrm{h}^{-1}\right)\end{array}$ & $\begin{array}{l}\text { Abundance } \\
\left(10^{9} \text { cells } 1^{-1}\right)\end{array}$ & $\begin{array}{l}\text { TdR incorp } \\
\left(\mathrm{pM} \mathrm{h} \mathrm{h}^{-1}\right)\end{array}$ & $\begin{array}{l}\text { Leu incorp } \\
\left(\mathrm{nM} \mathrm{h}^{-1}\right)\end{array}$ \\
\hline $23 \operatorname{Mar} 1989$ & 10.6 & 106.7 & 1.60 & 12.2 & 113.7 & 2.57 \\
\hline 15 May 1989 & 8.0 & 74.3 & 2.95 & 7.1 & 57.9 & 4.43 \\
\hline $10 \mathrm{Jul} 1989$ & 7.5 & 169.3 & 2.26 & 5.6 & 172.8 & 3.00 \\
\hline 11 Sep 1989 & 6.8 & 152.5 & 2.23 & 7.8 & 99.3 & 4.93 \\
\hline 6 Nov 1989 & 10.2 & 115.8 & 6.90 & 10.2 & 77.9 & 4.93 \\
\hline $16 \operatorname{Jan} 1990$ & 6.8 & 144.5 & 4.68 & 5.2 & 65.1 & 4.25 \\
\hline
\end{tabular}

on $\mathrm{TdR}$ incorporation. The corresponding values for Leu incorporation were 26 to $171 \mathrm{mg} \mathrm{C} \mathrm{m}^{-2} \mathrm{~d}^{-1}$ and 8 to $51 \mathrm{mg} \mathrm{N} \mathrm{m}^{-2} \mathrm{~d}^{-1}$.

The generation time of bacterial populations in the upper Laguna Madre was relatively uniform throughout the year $(31 \pm 7 \mathrm{~h})$, whereas the turnover time varied 3-fold (Table 2). The turnover time was similar to the generation time in September 1989 and January 1990, when production rates were high, but was longer during months when bacterial growth rates were low.

Bacterial parameters in the upper Laguna Madre were different from those in Baffin Bay, but differences were small. Bacterial abundances in Laguna Madre and Baffin Bay were within $20 \%$ of each other (Table 3 ). Rates of $\mathrm{TdR}$ incorporation were similar in Laguna Madre and Baffin Bay between March and July 1989, but were higher in Laguna Madre later in the year during September and November 1989 and January 1990 (Table 3). Rates of Leu incorporation were lower in Laguna Madre than in Baffin Bay, with the exception of November 1989 and January 1990 (Table 3).

\section{Diel variations in bacterial abundance and production}

During the diel surveys, the surface water flowed towards the northwest in the same direction as the prevailing southeasterly wind. Current speed was uniform during both studies and averaged $8.3 \mathrm{~m} \mathrm{~min}^{-1}$ in May and $7.8 \mathrm{~m} \mathrm{~min}^{-1}$ in July. Because the Laguna Madre has very limited exchange with the sea, tidally induced variations in depth of the water column are small and do not represent changes in water masses. During these diel surveys, depth of the water column varied by less than $6 \mathrm{~cm}$ (T. Amos unpubl.).

Rates of TdR and Leu incorporation over seagrass meadows were not significantly different from those over adjacent unvegetated sediments in May $(p=0.38$ for TdR and $p=0.28$ for Leu; Student's $t$-test) or in July ( $p=0.27$ for $T d R$ and $p=0.57$ for Leu; Student's $t$-test) (Figs. 3 \& 4). Incorporation rates of $\mathrm{TdR}$ and Leu increased during daytime, with maximal values in the early afternoon (Figs. 3 \& 4). Rates of TdR incorporation increased by a factor of 2.1 in May and 2.4 in July. The corresponding factor for Leu for both months was 1.8 . The daytime increase in bacterial production calculated by integrating the rates of $\mathrm{TdR}$ and Leu incorporation over the diel curve was $12 \mathrm{mg} \mathrm{C} \mathrm{m}^{-2}$ in May and $22 \mathrm{mg} \mathrm{C} \mathrm{m}{ }^{-2}$ in July (average increase of both days). The corresponding values derived from rates of Leu incorporation were $21 \mathrm{mg} \mathrm{C} \mathrm{m}{ }^{-2}$ in May and $13 \mathrm{mg} \mathrm{C}$ $\mathrm{m}^{-2}$ in July. Bacterial abundance was relatively constant over both diel surveys. Mean bacterial abundance was $7.8 \pm 0.3(\mathrm{SE}) \times 10^{9}$ cells $1^{-1}$ in May and $7.5 \pm 0.3$ $(\mathrm{SE}) \times 10^{9} \mathrm{cells}^{-1}$ in July.

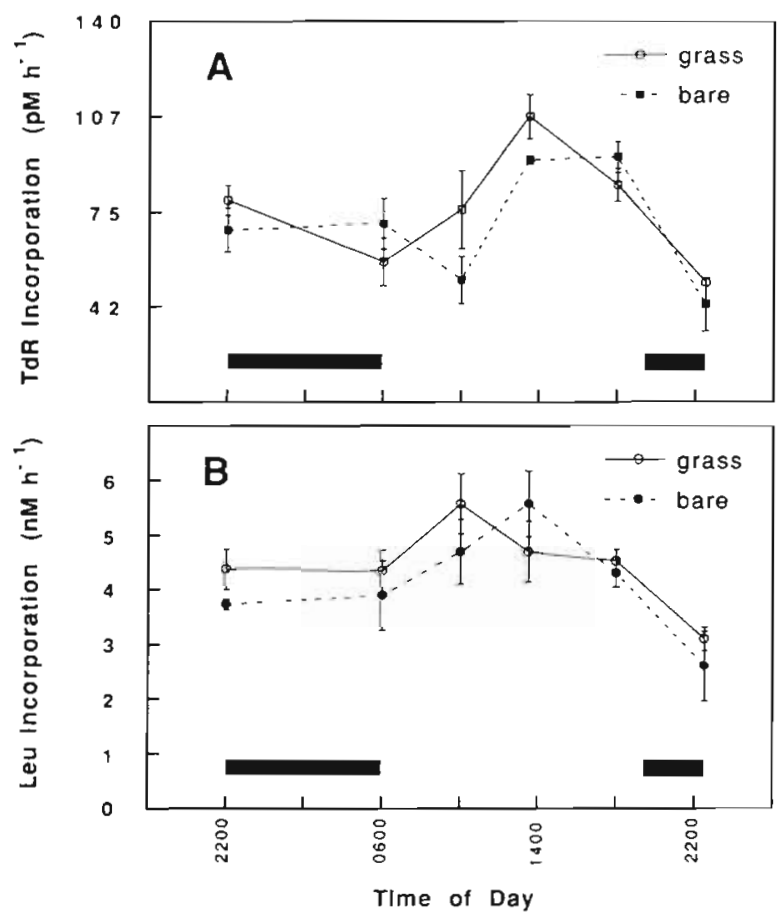

Fig. 3. Comparison of rates of (A) thymidine (TdR), and (B) leucine (Leu) incorporation over vegetated (grass) and unvegetated (bare) sediments at Stn A on 15-16 May 1989. Values are the average of independent samples (4 over seagrasses, 3 over bare sediment), each measured in duplicate. Error bars represent standard error of the measurements. Solid horizontal bars represent nighttime 


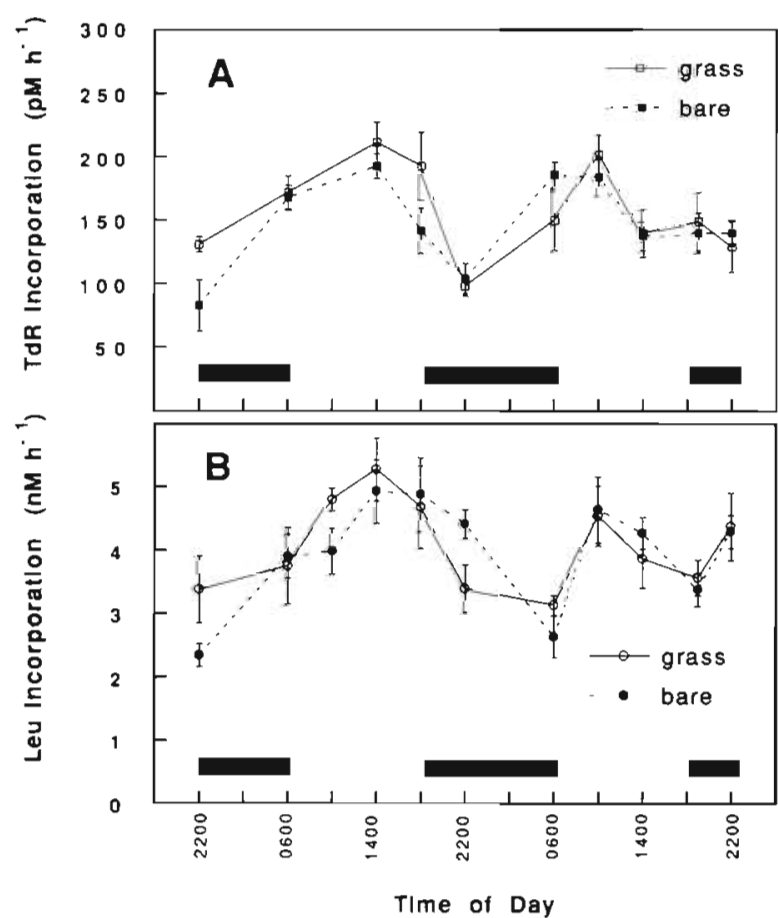

Fig. 4. Comparison of rates of (A) thymidine (TdR) and $(B)$ leucine (Leu) incorporation over vegetated (grass) and unvegetated (bare) sediments at Stn A on 10-12 July 1989. Two diel cycles were examined on this occasion. Values are the average of independent samples ( 3 over seagrasses, 3 over bare sediment), each measured in duplicate. Error bars represent standard error of the measurements. Solid horizontal bars represent nighttime

The response of bacteria to changes in water temperature was examined because the water temperature in Laguna Madre can change significantly over the diel cycle. In laboratory experiments, the response of bacteria to a range of temperatures $\left(22\right.$ to $\left.36^{\circ} \mathrm{C}\right)$ was linear $\left(\mathrm{r}^{2}=0.94\right.$ for $\mathrm{TdR}$ and 0.98 for Leu). For an increase in temperature from 29.0 to $32.5^{\circ} \mathrm{C}$, a range similar to that observed during the May study, the regression equation predicted a $20 \%$ increase in rates of $\mathrm{TdR}$ and Leu incorporation. A smaller increase of $10 \%$ was predicted for July, when the temperature variation over the diel cycle was $2^{\circ} \mathrm{C}$. Results from the diel studies did not indicate a significant correlation between temperature and rates of $\mathrm{TdR}$ or Leu incorporation. In May, the correlation coefficients between water temperature and $\mathrm{TdR}$ and Leu incorporation were $\mathrm{r}=0.46(\mathrm{p}=0.36)$ and $r=0.23(p=0.66)$, respectively. The corresponding values in July were $r=0.26(p=0.46)$ and $r=0.15$ $(p=0.66)$.

Bacterial production also varied over the diel cycle in Baffin Bay (Stn C), with higher values during daytime. In Baffin Bay, fluctuations in bacterial production were smaller (1.6-fold) than in Laguna Madre (Fig. 5A, B), and temperature appeared to play a greater role in regulating $\mathrm{TdR}$ and Leu incorporation ( $\mathrm{TdR}: \mathrm{r}=0.63$, $p=0.11 ;$ Leu. $r=0.52, p=0.12$ ). Changes in rates of $\mathrm{TdR}$ and Leu incorporation in Baffin Bay were in better agreement than those in Laguna Madre $(r=0.64, p=$ 0.03). In Laguna Madre, the correlation coefficient between rates of $\mathrm{TdR}$ and Leu incorporation in May was $\mathrm{r}=0.72(\mathrm{p}=0.11)$ and in July was $\mathrm{r}=0.55(\mathrm{p}=$ $0.10)$. Whereas the Leu: TdR ratio varied over the diel cycle in Laguna Madre, this ratio remained relatively constant in Baffin Bay (Fig. 5C).

\section{DISCUSSION} Estimating bacterial production using TdR and Leu
incorporation

Estimates of bacterial production are necessary for estimating carbon and energy flow through heterotrophic microorganisms, and for investigating the potential role of bacteria in the trophic dynamics of an ecosystem. Although the TdR method is commonly used to determine bacterial production, concerns have arisen regarding the accuracy of this approach due to the incorporation of $\mathrm{TdR}$ into macromolecules other than DNA (Hollibaugh 1988, Robarts \& Wicks 1989). In our procedures to estimate bacterial production, the DNA and protein fractions were separated to avoid the possible nonspecific incorporation of TdR. A significant fraction of the $\mathrm{TdR}$ incorporated by bacteria (mean = $43 \%$ ) was recovered in the protein fraction. In Laguna Madre and Baffin Bay, the amount of $T d R$ that was metabolized remained nearly constant over the course of the year.

Measuring rates of Leu incorporation into protein has been proposed as an independent method of estimating bacterial production (Kirchman et al. 1985). Rates of Leu and TdR incorporation have been shown to covary in various aquatic environments (Chin-Leo \& Kirchman 1988, Kirchman \& Hoch 1988). However, there are still very few comparisons of the $\mathrm{TdR}$ and Leu methods using natural samples and there is no information on how these indices compare over the seasonal cycle. In Laguna Madre, rates of $\mathrm{TdR}$ and Leu incorporation were significantly correlated over the seasonal cycle $(\mathrm{r}=0.62, \mathrm{p}=0.02)$ and gave nearly identical annual estimates of bacterial production $\left(24.50 \mathrm{~g} \mathrm{C} \mathrm{m}^{-2} \mathrm{yr}^{-1}\right.$ for $\mathrm{TdR}$ and $25.12 \mathrm{~g} \mathrm{C} \mathrm{m}^{-2} \mathrm{yr}^{-1}$ for Leu). The mean conversion factor for $\operatorname{TdR}\left(1.23 \pm 0.80 \times 10^{18}\right.$ cells $\mathrm{mol}^{-1}$ ) derived from the present study was in the range of theoretically determined factors $\left(0.3\right.$ to $2.0 \times 10^{18}$ cells mol ${ }^{-1}$; Bell 1988, Moriarty 1988). The mean Leu conversion factor $\left(4.27 \pm 3.31 \times 10^{16}\right.$ cells mol $\left.{ }^{-1}\right)$ was similar to the mean of those derived by Kirchman \& Hoch (1988) for the Delaware Bay $\left(5.80 \pm 2.01 \times 10^{16}\right.$ cells $\mathrm{mol}^{-1}$ ). 

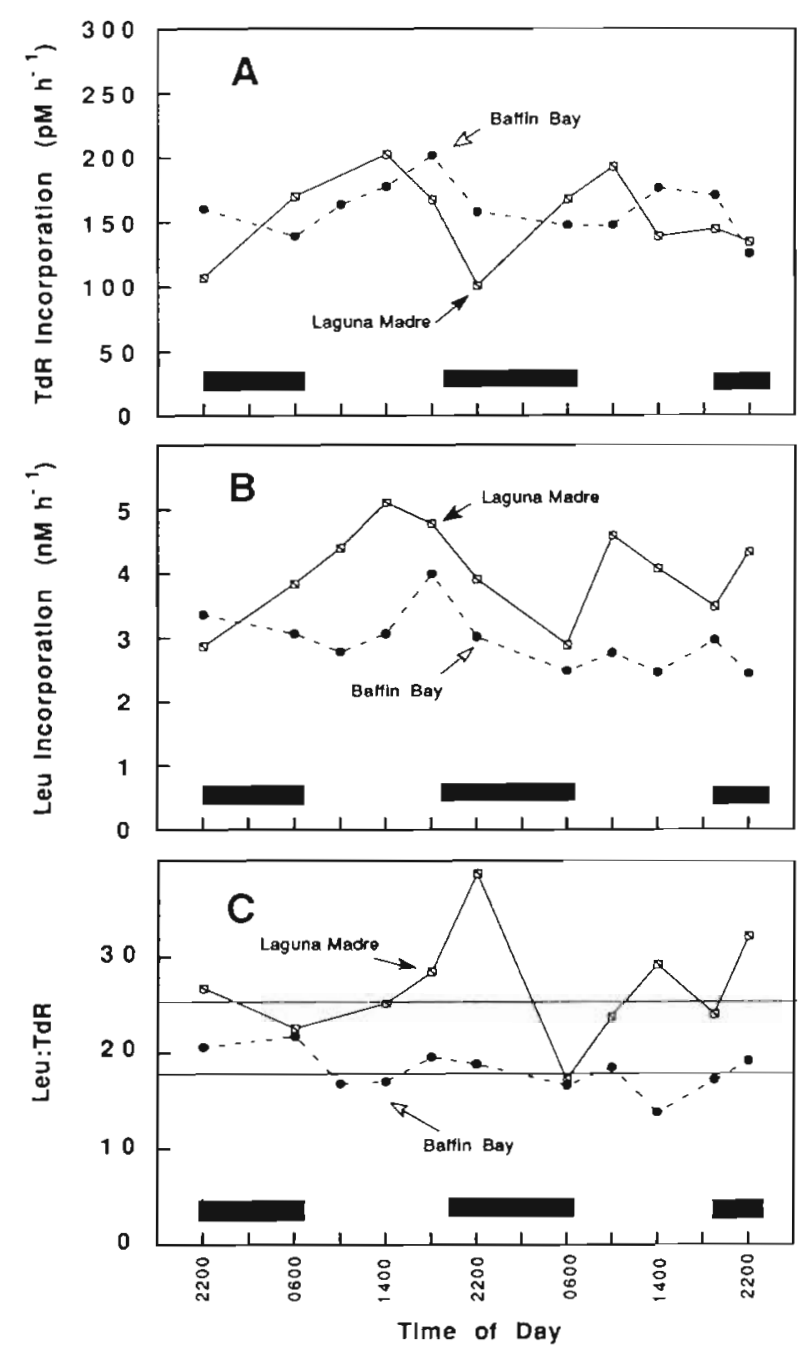

Fig. 5. Comparison of (A) thymidine (TdR) and (B) leucine (Leu) incorporation rates and $(C)$ the Leu : TdR ratio, at Stn B in Baffin Bay and Stn A in Laguna Madre. Laguna Madre values are the average of values over vegetated and unvegetated sediments. The upper horizontal line in (C) represents the average Leu: TdR ratio in Laguna Madre of $27 \pm 6$; the lower horizontal line represents the corresponding value for Baffin Bay of $18 \pm 2$

During the diel cycles, rates of TdR and Leu incorporation in Laguna Madre were not significantly correlated. The correlation coefficient between rates of TdR and Leu incorporation in May was $r=0.72(p=0.11)$ and in July was $r=0.55(p=0.10)$. Chin-Leo \& Kirchman (1990) proposed that lack of agreement between rates of $\mathrm{TdR}$ and Leu incorporation on the time scale of hours could be explained by unbalanced growth of bacteria. In pure cultures of bacteria, protein synthesis changes before DNA synthesis prior to shifts in bacterial growth rates (Ingraham et al. 1983). Similarly, rates of Leu incorporation change before changes in $\mathrm{TdR}$ incorporation in natural assemblages of bacteria prior to shifts in growth rate (Chin-Leo \& Kirchman
1990). Unbalanced growth in nature may indicate periads when bacterial growth rates are changing in response to variations in the environment. We do not know what factors may cause unbalanced growth in the Laguna Madre, but we can speculate on some possibilities. Over the diel cycle bacterial production was highest during the day, suggesting a response to some light-mediated process. Fluctuations in the growth environment of bacteria could be caused by rapid changes in the quantity or quality of DOM from the release of seagrass photosynthate or by changes in water temperature. In contrast to Laguna Madre, rates of TdR and Leu in Baffin Bay were in better agreement, suggesting that the growth environment of bacteria in Baffin Bay was more uniform (Fig. 5C).

Simon (1988) found good agreement between seasonal changes in turnover time and changes in the generation time of bacteria, suggesting that biomass turnover rates may be good indicators of bacterial growth. In the present study, biomass turnover times of bacteria did not always agree with the generation time (Table 3). Although generation time and turnover time are both estimates of the doubling time of the bacterial population, estimates of bacterial growth in terms of turnover time are complicated by the presence of grazers. For example, the activity of grazers may promote bacterial production by providing remineralized nutrients. In addition, comparisons between generation times and turnover times are confounded by the very different experimental manipulations involved. Derivation of the generation time requires filtration, dilution of the bacteria and an incubation period lasting several hours, whereas derivation of the turnover time involves shorter incubations (30 min) and fewer manipulations.

\section{Seasonal variations in bacterial production}

Over the seasonal cycle bacterioplankton production in the upper Laguna Madre appeared to respond to changes in water temperature. Rates of $T d R$ and Leu incorporation were generally higher during warmer months than during cooler months (Fig. 2A, C). Moriarty et al. (1990) found in seagrass communities in Australia that shifts in water temperature led to greater variations in bacterial activity than in primary production. Temperature was also found to be a dominant factor regulating bacterial degradation of plant detritus in a temperate salt marsh and a freshwater wetland (Benner et al. 1986a). However, in Laguna Madre temperature and bacterioplankton production were not strongly correlated, indicating that other seasonally dependent factors also influenced bacterial growth. The availability of DOM is likely to be an important factor regulating bacterial production (Cole et al. 1988, 
Kirchman 1990), and the production of substrates utilized by bacteria in Laguna Madre may vary seasonally. Bacteria utilize DOM released by living seagrasses and phytoplankton, and this release may be greatest during summer, when rates of photosynthesis are maximal. The senescence and decomposition of seagrass detritus also release significant quantities of DOM to the water column. Seagrasses lose a substantial fraction of their biomass as DOM during the early stages of decomposition (Mann 1988, Harrison 1989). In Laguna Madre, a large pool of DOM may be released in fall following the major die-back of seagrasses. This pulse of DOM could contribute to the high bacterial production during fall (Fig. 2A) and may explain the high bacterioplankton production in Laguna Madre as compared to the phytoplankton-dominated Baffin Bay during September and November 1989 and January 1990 (Table 3). The response of bacteria to short-term changes in environmental conditions may also change the expected relationship between bacterial production and temperature. For example, the high rainfall in October 1989 coincided with unexpected high incorporation rates of Leu (Fig. 2A). Furthermore, the massive fish kill following the severe freeze in January 1990 coincided with elevated rates of $\mathrm{TdR}$ and Leu incorporation (Fig. 2).

\section{Diel variations of bacterial production}

Bacterial production was enhanced during daytime (Figs. 3, 4 \& 5), suggesting a response of bacteria to photosynthesis. Moriarty \& Pollard (1982) also found significant diurnal increases in $\mathrm{TdR}$ incorporation by bacteria in seagrass meadows. Moriarty et al. (1986) later demonstrated that bacteria utilized the DOM released by living seagrasses. In the Laguna Madre, we estimated that most of the diurnal increase in bacterial production could be accounted for by the growth of bacteria on seagrass photosynthate and by the increase of bacterial metabolism due to daytime increases in water temperature. The daytime increase of bacterial production in the upper Laguna Madre based on TdR incorporation in May and July was 12 and $22 \mathrm{mg} \mathrm{C} \mathrm{m}^{-2}$ respectively. Assuming a $30 \%$ growth efficiency of bacteria (Benner et al. 1988), 40 and $73 \mathrm{mg} \mathrm{C} \mathrm{m}^{-2}$ would be required to support this production. The daily production of Halodule wrightii in the upper Laguna Madre was $1.8 \mathrm{~g} \mathrm{C} \mathrm{m}^{-2}$ in May and $5.2 \mathrm{~g} \mathrm{C} \mathrm{m}^{-2}$ in July (K. Dunton unpubl.). Assuming a $1 \%$ loss of photosynthate to the water column by $H$. wrightii (Moriarty et al. 1986) and that all of the DOM released was utilized by bacteria, released photosynthate could support 46 and $72 \%$ of the diurnal increase in bacterial production in May and July respectively. Using the Leu values, the hypothesized released photosynthate could support
$74 \%$ of the daytime increase in bacterial production in May and $42 \%$ of the daytime increase in July. The magnitude of the response of bacteria to changes in temperature estimated from laboratory experiments could account for about 20 and $10 \%$ of the daytime increase in bacterial production in May and July respectively.

During the diel studies, we sampled in complete darkness at 22:00 and 06:00 h. In May, bacterial production was similar at both times, suggesting no changes during the night (Fig. 3). However, in July, values at 22:00 h were generally lower than values at 06:00 h, indicating nighttime increases in bacterial production (Fig. 4). Jørgensen et al. (1981) found that the seagrasses Cymodocea nodosa and Posidonia oceanica released dissolved free amino acids during the night. Similar nocturnal releases of DOM from Halodule wrightii may stimulate bacterial production in the Laguna Madre. It is possible that DOM released during the day continued to be used during the night.

Although seagrasses dominate primary production in Laguna Madre and are the major contributors to the DOM pool, we could not discount the role of algal photosynthate in controlling the diel variation of bacterial production. There were no significant differences between rates of bacterial production over vegetated and unvegetated sediments (Figs. $3 \& 4$ ). In contrast, Moriarty \& Pollard (1982) found significant differences between bacterial production over seagrasses and over bare sediments only $2 \mathrm{~m}$ away. If the response time of the bacteria to inputs of leaked photosynthate was slower than the time $(\sim 1 \mathrm{~min})$ necessary for bacteria to traverse the length of the bare patch $(\sim 10 \mathrm{~m})$, a gradient in bacterial production between vegetated and unvegetated sediments would not be apparent. However, in May, we did not find significant differences in bacterial production between vegetated and unvegetated sites during the daytime, even after the winds and the currents had subsided.

\section{Trophic implications}

Bacterioplankton in the upper Laguna Madre represent a substantial pool of carbon and nitrogen potentially available to higher trophic levels. Over the year, assuming a carbon and nitrogen content of $20 \mathrm{fg} \mathrm{C}$ and $6 \mathrm{fg} \mathrm{N}$ cell $^{-1}$ (Lee \& Fuhrman 1987), the mean standing stock of bacteria was $154 \pm 37 \mathrm{mg} \mathrm{C} \mathrm{m}^{-2}$ and $46 \pm$ $11 \mathrm{mg} \mathrm{N} \mathrm{m}{ }^{-2}$. Rates of bacterioplankton production on an areal basis ranged from 19 to $192 \mathrm{mg} \mathrm{C} \mathrm{m}^{-2} \mathrm{~d}^{-1}$, which is higher than the range $(10$ to $100 \mathrm{mg} C$ $\mathrm{m}^{-2} \mathrm{~d}^{-1}$ ) reported from seagrass meadows in the Gulf of Carpentria, Australia (Moriarty et al. 1990). On a volume basis, bacterial production in Laguna Madre 
(19 to $192 \mu \mathrm{g} \mathrm{C} \mathrm{l}^{-1} \mathrm{~d}^{-1}$ ) was also high when compared to the range of values reported for pelagic systems $(0.4$ to $150 \mu \mathrm{g} \mathrm{C} \mathrm{l} \mathrm{C}^{-1} \mathrm{~d}^{-1}$ ) (Cole et al. 1988). Our estimates of bacterioplankton production are conservative estimates of above-ground bacterial production, because substantial bacterial growth may also occur on the surfaces of living (Kirchman et al. 1984) and detrital seagrass blades.

In Laguna Madre, the yearly bacterial production estimated from rates of $\mathrm{TdR}$ and Leu incorporation was $25.18 \mathrm{~g} \mathrm{C} \mathrm{m}^{-2} \mathrm{yr}^{-1}$ and $7.45 \mathrm{~g} \mathrm{~N} \mathrm{~m}^{-2} \mathrm{yr}^{-1}$. The aboveground production of Halodule wrightii at Stn A during 1989 was estimated to be $723 \mathrm{~g} \mathrm{C} \mathrm{m}^{-2} \mathrm{yr}^{-1}$ (K. Dunton unpubl.). The corresponding phytoplankton production was $78 \mathrm{~g} \mathrm{C} \mathrm{m}^{-2} \mathrm{yr}^{-1}$ (D. Stockwell unpubl.). Epiphytes may also be significant primary producers in seagrass communities, sometimes accounting for $70 \%$ of the above-ground seagrass biomass (Morgan \& Kitting 1984). However, in Laguna Madre, epiphytes constituted $<2 \%$ of the above-ground seagrass biomass (K. Dunton unpubl.).

At the ecosystem level, assuming a carbon conversion efficiency of $30 \%$ (Benner et al. 1988), and considering that Halodule wrightii covers about $70 \%$ of the surface area of Laguna Madre (C. Onuf unpubl.), bacterioplankton growth accounted for $15 \%$ of the total primary production (seagrasses and phytoplankton), $17 \%$ of the yearly above-ground production of $H$. wrightii, or $103 \%$ of the phytoplankton production. In terms of nitrogen, using a $\mathrm{C}: \mathrm{N}$ atomic ratio of 17 for $H$. wrightii (Opsahl \& Benner unpubl.) and 7 for phytoplankton (Redfield ratio), bacterial growth accounted for $51 \%$ of the total primary production, $70 \%$ of the seagrass production and $186 \%$ of the phytoplankton production. Comparisons between the rates of nitrogen production by bacteria and primary producers are confounded, however, because of the large differences in turnover times of these organisms and the potential for rapid recycling of nitrogen. Furthermore, bacterial nitrogen conversion efficiencies are likely to be different from those of carbon.

The bulk of the pool of DOM in Laguna Madre probably originates from the senescence and decomposition of seagrasses. A large percentage $(\sim 35 \%)$ of the organic matter in Halodule wrightii detritus is lost due to rapid leaching of DOM during the first $30 \mathrm{~d}$ of decomposition (Benner unpubl.). The remaining tissues continue to be a source of DOM, albeit at a lower rate, throughout the year. Kirkman \& Reid (1979) found that, over the course of a year, up to $48 \%$ of the leaf production in the seagrass Posidonia australis was lost in the form of dissolved organic carbon. A small fraction of this loss by seagrasses appears to be due to the release of DOM during photosynthesis (Penhale \& Smith 1977 , Wetzel \& Penhale 1979, Moriarty et al. 1986). H. wrigh- tii exuded about $1 \%$ of incorporated ${ }^{14} \mathrm{C}$ into the water column (Wetzel \& Penhale 1979, Moriarty et al. 1986).

Even though seagrasses dominate primary production in the Laguna Madre and are likely to be the major contributors to the DOM pool, the role of phytoplankton-derived DOM in supporting a large fraction of the bacterial production cannot be ruled out. There were no significant differences in bacterioplankton production above vegetated and unvegetated sediments, and the differences in bacterial parameters between Laguna Madre and phytoplankton-dominated Baffin Bay were small. Although the annual bacterial production is higher than that of the phytoplankton, phytoplankton production could still support a substantial fraction of the bacterial production because organic carbon can be recycled throughout the food web (Strayer 1988). However, it is unlikely that phytoplankton production alone could support a major fraction of the bacterioplankton production. In Laguna Madre $>90 \%$ of the daily phytoplankton production is consumed by grazers (D. Stockwell unpubl.) and a substantial fraction of this carbon leaves the system as respiratory losses.

In Laguna Madre, the relative constancy of bacterial abundance, together with high rates of bacterial production, indicates rapid removal of cells from the water column (Table 3). Experiments using the eucaryotic inhibitor cycloheximide showed increases in bacterial numbers that matched the rate of bacterial production estimated from rates of TdR incorporation. Although these experiments were not repeated throughout the year, they suggest that eucaryotes, not bacteriophages (Proctor \& Fuhrman 1990), were responsible for the removal of bacteria. The high densities of bacterioplankton in Laguna Madre and their rapid turnover indicate that bacteria represent a substantial pool of organic matter potentially available for higher trophic levels. In order to determine whether the growth of bacteria on seagrass-derived organic matter and grazing of bacterioplankton biomass contribute significantly to the high animal productivity of the Laguna Madre ecosystem, it is still necessary to determine the sources of substrate that support bacterial growth, the growth efficiency of bacteria on these substrates, and the efficiency of transfer to animals in the food web.

Acknowledgements. This research was supported by grant ATP4541 from the Texas Higher Education Coordinating Board, grant NA89AA-D-SG139 from the NOAA Office of Sea Grant, and NSF grant BSR8910766. We are grateful to Tony Amos, Ken Dunton, Chris Onuf, Pat Parker and Dean Stockwell for sharing unpublished data. We also wish to thank the captain and crew of the RV 'Longhorn' for assistance in field sampling, and to the King Ranch management for allowing access to their property. We thank Steve Opsal, Dean Pakulski and 2 anonymous reviewers for useful suggestions. This paper is contribution 806 from the Marine Science Institute of the University of Texas at Austin. 


\section{LITERATURE CITED}

Bell, R. $\Upsilon$ (1988). Thymidine incorporation and estimates of bacterioplankton production: are the conversion factors valid? Arch. Hydrobiol. (Beih. Ergebn. Limnol.) 31. $163-171$

Benner, R, K'nees, J. L., Hodson, R. E. (1988). Carbon conversion efficiency for bacterial growth on lignocellulose: implication for detritus-based food webs. Limnol. Oceanogr 33: 1514-1526

Benner, R., Maccubbin, A. E., Hodson, R. E. (1986a). Temporal relationship between the deposition and microbial degradation of lignocellulosic detritus in a Georgia salt marsh and the Okefenokee Swamp. Microb. Ecol. 12: 291-298

Benner, R., Moran, M. A., Hodson, R. E. (1986b). Biogeochemical cycling of lignocellulosic carbon in marine and freshwater ecosystems: relative contributions of procaryotes and eucaryotes. Limnol. Oceanogr 31: 89-100

Benner, R. Peele, E. R. Hodson, R. E. (1986c). Microbial utilization of dissolved organic matter from leaves of the red mangrove, Rhizophora mangle, in the Fresh Creek Estuary, Bahamas. Estuar. coast. Shelf Sci. 23: 607-619

Chin-Leo, G., Kirchman, D. L. (1988). Estimating bacterial production in marine waters from the simultaneous incorporation of thymidine and leucine. Appl. environ. Microbiol. 54: 1934-1939

Chin-Leo, G., Kirchman, D. L. (1990). Unbalanced growth in natural assemblages of marine bacterioplankton. Mar. Ecol. Prog. Ser, 63: 1-18

Cole. J. J., Findlay, S., Pace, M. L. (1988). Bacterial production in fresh and saltwater ecosystems: a cross-system overview. Mar. Ecol. Prog. Ser. 43: 1-10

Cromwell, J. E. (1971). Barrier coast distribution: a world wide survey. Proc. of the Second Natl. Coastal and Shallow Water Research Conf. NSF/ONR, p. 408

Ducklow, H. W., Purdie, D. A., Williams, P. J. LeB., Davies, M. (1986). Bacterioplankton: a sink for carbon in a coastal marine plankton community. Science 232: 865-867

Findlay, S., Carlough, L., Crocker, M. T., Gill, H. K., Meyer, J. L., Smith, P. J. (1986). Bacterial growth on macrophyte leachate and fate of bacterial production. Limnol. Oceanogr. 31: 1335-1341

Fry, B., Parker, P. L. (1979). Animal diet in Texas seagrass meadows: ${ }^{13} \mathrm{C}$ evidence for the importance of benthic plants. Estuar. coast mar Sci. 8: 499-509

Fuhrman, J. A., Azam, F. (1982). Thymidine incorporation as a measure of heterotrophic bacterioplankton production in marine surface waters; evaluation and field results. Mar Biol. 66: 109-120

Harrison, P. G. (1989). Detrital processing in seagrass systems: a review of factors affecting decay rates, remineralization and detritivory. Aquat. Bot. 23: 263-268

Hedgpeth, J. W. (1947). The Laguna Madre of Texas. Publs Inst mar Sci. Univ. Texas 3 (1): 107-224

Hedgpeth, J. W. (1967). Ecological aspects of the Laguna Madre, a hypersaline estuary. In: Lauff, G. H. (ed.) Estuaries. Publ. No. 83. American Association for the Advancement of Science, Washington, D.C., p. 408-419

Hollibaugh, J. T (1988). Limitations of the $\left[{ }^{3} \mathrm{H}\right]$ thymidine method for estimating bacterial productivity due to thymidine metabolism. Mar. Ecol. Prog. Ser. 43: 19-30

Ingraham, J. L., Maaloe, O., Neidhardt, F. C. (1983). Growth of the bacterial cell. Sinauer Assoc, Sunderland, Massachusetts.

Jergensen, N. O. G., Blackburn, T H., Henriksen, K., Bay, D. (1981). The importance of Posidonia oceanica and Cymo- docea nodosa as contributors of free amino acids in water and sediment of seagrass beds. P.S.Z.N.I. Mar. Ecol. 2 (2): $97-113$

Kirchman, D. L. (1990). Limitation of bacterial growth by dissolved organic matter in the subarctic Pacific. Mar. Ecol. Prog. Ser 62: 47-54

Kirchman, D. L., Ducklow, H. W., Mitchell, R. (1982a). Estimates of bacterial growth from changes in uptake rates and biomass. Appl environ. Microbiol. 44: 1296-1307

Kirchman, D. L., Hoch, M. P. (1988). Bacterial production in the Delaware Bay estuary estimated from thymidine and leucine incorporation rates. Mar Ecol. Prog. Ser 45: $169-178$

Kirchman, D. L., K'nees, E., Hodson, R. (1985). Leucine incorporation and its potential as a measure of protein synthesis by bacteria in natural aquatic systems. Appl. environ. Microbiol. 49: 599-607

Kirchman, D. L., Mazella, L., Alberte, R. S., Mitchell, R. (1984). Epiphytic bacterial production on Zostera marina. Mar. Ecol. Prog. Ser. 15: 117-123

Kirchman, D. L., Sigda, J., Kapuscinski, R., Mitchell, R. (1982b). Statistical analysis of the direct count method for enumerating bacteria. Appl. environ. Microbiol. 44: $376-382$

Kirkman, H., Reid, D. D. (1979). A study of the role of the seagrass Posidonia australis in the carbon budget of an estuary. Aquat. Bot. 7: 173-183

Lee, S., Fuhrman, J. A. (1987). Relationships between biovolume and biomass of naturally derived marine bacterioplankton. Appl. environ. Microbiol. 53: 1298-1303

Mann, K. H. (1988). Production and use of detritus in various freshwater, estuarine, and coastal marine ecosystems. Limnol. Oceanogr. 33: 910-930

Moran, M. A., Hodson, R. E. (1989). Formation and bacterial utilization of dissolved organic carbon derived from detrital lignocellulose. Limnol. Oceanogr 34 (6): 1034-1047

Moran, M. A., Legovic, T., Benner, R., Hodson, R. E. (1988). Carbon flow from lignocellulose: a simulation analysis of a detritus-based ecosystem. Ecology 69 (5): 1525-1536

Morgan, M. D., Kitting, C. L. (1984). Productivity and utilization of the seagrass Halodule wrightii and its attached epiphytes. Limnol. Oceanogr. 29 (5): 1066-1076

Moriarty, D. J. W (1988). Accurate conversion factors for calculating bacterial rates from thymidine incorporation into DNA: elusive or illusive? Arch. Hydrobiol. (Beih. Ergebn. Limnol.) $31 \quad 211-217$

Moriarty, D. J. W., Iverson, R. L., Pollard, P. C. (1986). Exudation of organic carbon by the seagrass Halodule wrightii Aschers. and its effect on bacterial growth in the sediment. J. exp. mar. Biol. Ecol. 96: 115-126

Moriarty, D. J. W., Pollard, P. C. (1982). Diel variation of bacterial productivity in seagrass (Zostera capricorni) beds measured by rate of thymidine incorporation into DNA. Mar. Biol. 72: 165-173

Moriarty, D. J. W., Roberts, D. G., Pollard, P. C. (1990). Primary and bacterial seagrass communities in the Gulf of Carpentaria, Australia. Mar. Ecol. Prog. Ser 61: 145-157

Nixon, S. W. (1982). Nutrient dynamics, primary production and fisheries yields of lagoons. Actes Symposium International sur les lagunes (côtières SCOR/IABO/UNESCO Bordeaux, 8-14 septembre 1981 Oceanol. Acta SP: $357-371$

NOAA (1985). National estuarine atlas, Vol 1, Physical and hydrologic characteristics, Chap. 3, Gulf of Mexico. National Oceanographic and Atmospheric Administration, Washington, D.C.

Odum, H. T., Wilson, R. F. (1962). Further studies on reaera- 
tion and metabolism of Texas bays, 1958-1960. Publs Inst. mar. Sci. Univ. Tex. 8: 23-55

Penhale, P. A., Smith, W. O. (1977). Excretion of dissolved organic carbon by eelgrass (Zostera marina) and its epiphytes. Limnol. Oceanogr. 22: 400-407

Porter, K. G., Feig, Y S. (1980). The use of DAPI for identifying and counting aquatic microflora. Limnol. Oceanogr. 25: 943-948

Proctor, L. M., Fuhrman, J. A. (1990). Viral mortality of marine bacteria and cyanobacteria. Nature, Lond. 343: 60-62

Riemann, B., Bjornsen, P. K., Newell, S., Fallon, R. (1987). Calculation of cell production of coastal marine bacteria based on measured incorporation of $\left[{ }^{3} \mathrm{H}\right]$ thymidine. Limnol. Oceanogr. 32 (2): 471-4.76

Robarts, R. D., Wicks, R. J. (1989). Methyl- ${ }^{3} \mathrm{H}$ thymidine macromolecular incorporation and lipid labeling: their significance to DNA labeling during measurements of aquatic bacterial growth. Limnol. Oceanogr. 34: 213-222

This article was presented by S. Y. Newell, Sapelo Island, Georgia, USA
Sherr, E. B., Sherr, B. F., Albright, L. J. (1987). Bacteria: link or sink? Science 235: 88-89

Simon, M. (1988). Growth characteristics of small and large free-living and attached bacteria in Lake Constance. Microb. Ecol. 15: 151-163

Strayer, D. (1988). On the limits to secondary production. Limnol. Oceanogr. 33: 1217-1220

Texas Parks and Wildlife Dept (1988). Trends in Texas commercial fishery landings, 1977-1987. Management data series, No. 149. Texas Parks and Wildlife Department, Coastal Fisheries Branch, Austin, Texas

Valiela, I., Koumian, L., Swain, I., Teal, J. M., Hobbie, J. E. (1979). Cinnamic acid inhibition of detritus feeding. Nature, Lond. 280: 55-57

Wetzel, R. G., Penhale, P. A. (1979). Transport of carbon and excretion of dissolved organic carbon by leaves and roots/ rhizomes in seagrasses and their epiphytes. Aquat. Bot. 6: $149-158$

Manuscript first received: December 6, 1990

Revised version accepted: April 22, 1991 